\title{
BENCHMARKING SUPPLIER DEVELOPMENT: AN EMPIRICAL CASE STUDY OF VALIDATING A FRAMEWORK TO IMPROVE BUYER-SUPPLIER RELATIONSHIP
}

\author{
Khuram Shahzad ${ }^{1}$, Ilkka Sillanpää ${ }^{2}$, Elina Sillanpääa ${ }^{3}$, Shpend Imeri ${ }^{4}$ \\ 1 University of Vaasa, Faculty of Technology (Department of Production), Finland \\ ${ }^{2}$ University of Vaasa, Faculty of Business Studies (Department of Management), Finland \\ 3 Tampere University of Technology, Faculty of Business and Built Environment (Department of Civil Engineering), \\ Finland \\ ${ }^{4}$ High Level Training Institute, Macedonia
}

\author{
Corresponding author: \\ Ilkka Sillanpää \\ University of Vaasa \\ Faculty of Business Studies \\ Management Department \\ Wolffintie 3465200 Vaasa, Finland phone: (+358) 407777167 \\ e-mail: ilkka.j.sillanpaa@gmail.com
}

Received: 21 December 2015 Accepted: 17 February 2016

\section{Abstract}

In today's dynamic business environment, firms are required to utilize efficiently and effectively all the useful resources to gain competitive advantage. Supplier development has evolved as an important strategic instrument to improve buyer supplier relationships. For that reason, this study focuses on providing the strategic significance of supplier development approaches to improve business relationships. By using qualitative research method, an integrated framework of supplier development and buyer-supplier relationship development has been tested and validated in a Finnish case company to provide empirical evidence. It particularly investigates how supplier development approaches can develop buyer-supplier relationships. The study present a set of propositions that identify significant supplier development approaches critical for the development of buyer-supplier relationships and develop a theoretical framework that specifies how these different supplier development approaches support in order to strengthen the relationships. The results are produced from an in-depth case study by implementing the proposed research framework. The findings reveal that supplier development strategies i.e., supplier incentives and direct involvements strongly effect in developing buyer-supplier relationships. Further research may focus on considering indepth investigation of trust and communication factors along with propositions developed in the study to find out general applicability in dynamic business environment. Proposed integrated framework along with propositions is a unique combination of useful solutions for tactical and strategic management's decision making and also valid for academic researchers to develop supplier development theories.

\section{KEYWORDS}

supplier development, supplier management, strategic competitive advantage, buyer-supplier relationship, supply chain management, case study.

\section{Introduction}

In recent years, supplier development activities are defined as the most important effort that firms undertake not only to gain competitive advantage but to develop suppliers for long term partnership and relationship enhancement. Several strategic sus- tainable activities are involved in developing the core capabilities of suppliers' that are utilized across industries [1]. Reference [2] argues that different supplier development efforts exist but they fluctuate based on the firm's commitment and dedication towards supplier development. Similarly, the increased interest in supplier development and buyer-supplier re- 
lationship result in highlighting the importance of strategic collaboration of buyers and suppliers to enhance the operational performance and to build-up stronger and long-term relationships [3]. Suppliers are the most important capability and critical input resource for firms to produce a significant product or service and that is the reason now firms are implementing supplier development programs. This does not provide only competitive advantage to the firms but also long-term relationships with their potential suppliers [4].

Supplier development efforts increase the competencies of both buyers and suppliers that results in successful operational performance. The success aspects include but not limited to: effective two-way communication, an attitude of partnership, shared promises and management support [5] and [6]. Those factors lead toward successful supplier development, continuous performance improvement and strategically developing buyer-supplier relationships [7]. Similarly, the process model of reference [8] proposes five successful factors (e.g. supplier's team leadership, top management commitment, capable jointdevelopment team, data driven changes, and success of a model line) that influence in enhancing the supplier development efforts. In the similar way, top management commitment has become a critical success factor in value-based supply chain innovation which provides a wide range of opportunities to become competitive. Reference [5] and [9] have come up with the conclusion that supplier development programs including supplier evaluation, training and awards help to communicate with supplier effectively. These efforts develop a narrative of successful partnership with suppliers and to remain competitive.

Suppliers signify critical resources which provide essential materials and services to a firm for production. The quality and cost of a product is always on the stake and firms are more careful to evaluate the capabilities and competencies of suppliers because it also provides opportunity to suppliers to develop their capabilities. Therefore, organizations are more eager now than ever to implement supplier development programs not only in maintaining competitive advantage but also to develop strong buyer-supplier relationships [4] and [10]. In the same vein, reference [4] provide some successful corporate examples where supplier development has been implemented successfully to achieve continuous improvement; reduced supply based cost, improved quality and delivery, lead time, and improved productivity.

Further, reference [11] state that developing suppliers need efforts for long term cooperation which leads towards the improvement in suppliers' techni- cal, quality, delivery, and cost capabilities. Firms are eager to take supplier development initiatives and transfer knowledge into their supply base to improve supplier performance [12]. On the other hand, [4] discover a research gap by highlighting the ineffectiveness of those efforts and initiatives in supplier performance. They have highlighted the critical role of communication in buyer-supplier relationship which is untested in context of supplier development.

Despite the much appreciation of importance of efficiently developing suppliers and buyer-supplier relationship, gaps remain in understanding the significant supplier development factors that strategically develop buyer-supplier relationship. Theoretical and empirical evidence of supplier development strategies and buyer-supplier relationship is highly fragmented; focused separately with little understanding, and hence limited cumulative learning. This research addresses this research gap by implementing and validating a developed integrated research framework through a case study. Reference [3] proposes an integrated research framework based on detailed theoretical literature review, and this study is a step forward to implement and validate the research framework in a case study. This study compliments their research and provides the empirical evidence of step by step supplier development strategies, approaches and their strategic impact on business relationships.

This study is quite important in its nature because it fills the research gap by providing empirical evidence of integrated framework of supplier development strategies that become important reasons to develop long-term relationships. Such an integrated research approach helps to uncover rich explanations about the management of suppliers and buyer-supplier relationships. As a consequence, this study investigates the following research question: How supplier development framework leads towards strategic value-added buyer-supplier relationships?

This research identifies and addresses above mentioned question by empirically investigating a link between step by step supplier development program and buyer-supplier relationship performance outcomes. The remainder of this study is organized as follows. In the next section, literature review is presented in order to develop an understanding of the link between supplier development and buyersupplier relationship. This is followed by a description of empirical section which presents research methodology used in this study. Next section provides results with discussion of supplier development strategies and their impact on business relationships. After presenting the discussion and implications of the results, the paper concludes with some manage- 
rial implications, limitations and suggestions for further research.

\section{Literature review}

Supplier development and buyer-supplier relationship are significant fields of research in global supply chain management where diversity of skills and knowledge provide effective competitiveness and improved performance to both parties [6]. Firms are more eager in supplier development programs not only to continue long term relationship with their suppliers but also to develop strategically global competitive advantage [13]. Further, [8] proposed a model consisting five supplier development factors. Those factors include; supplier's top executives commitment, capable joint-development team, supplier's leadership, accomplishment of a model line, and data driven changes. Reference [14] highlighted the buyer's inclination to involve in supplier development programs where communication, buyer-supplier relationship endurance, and obligations of suppliers are taken under consideration.

The concept of supplier development was originated by [15] to describe the willpower of manufactures in enhancing the numbers of suppliers for the purpose of improved performance. This idea was then left with an open discussion platform for the researchers in supply chain management where the discussion started with the complex product businesses and their suppliers [16] and [17]. On the other hand, [14] provided a different aspect of supplier development called "the antecedents" which explains the actions to be taken before supplier development programs. He highlighted those antecedents as the important inputs for supplier development including strategic supplier management, purchasing functions as a source of competitive advantage, investments in supplier's competencies, commitments, supplier as partners, communication, and information sharing.

Several researchers have highlighted the importance of supplier's competencies and capabilities in manufacturing firm's competitive advantage. Similarly, researchers pointed the important aspects of supplier development programs in supply chain management literature (i.e., performance measurement, supplier evaluation, setting goals for suppliers, training etc.) that play a pivotal role in maintaining improved performance of manufacturing firms $[18,5$, $11]$ and [19].

\section{Supplier development approaches}

Recent trends in manufacturing firms show refocusing strategies on the core capabilities while in- creased outsourced activities and effectively using all resources to gain competitive advantage [20] and [4]. Supplier performance has become very important for manufacturing firms' long term relationships, quality and cost of the products and services, efficient supplier network and successful outcomes. For that reason, buyers are eager to implement increasingly supplier development strategies and approaches in their operations to sustain proficient and high performance supply base. Those approaches include assessment of suppliers, performance incentives, initiating suppliers' competition, and buying firm's own direct interest in development of suppliers through training of supplier's personnel [20] and [4].

In a very rich literature of supply chain management, researchers have examined supplier's perspective in discussion of business relationships for supplier development approaches. For the reason, many researchers highlighted the importance of suppliers for buying firms operational performance and suggested to consider suppliers their virtual extension. Further, they have found combined inter-organizational communication as the most important prerequisite in converting an organization's efforts in supplier development [14, 21-23] and [4]. On the other hand, supplier commitment, trust, and alignment of organizational culture have been noticed by many researchers as antecedents to supplier development [24] and [8]. While, others highlighted suppliers as partners through motivations of their acknowledgement, buying firms' direct involvements, efficient communication between them, and multiple contracts to keep the competition up between suppliers. These factors transform buying firm's efforts not only into supplier development but to improve operational performance and competencies $[2,5]$ and $[9]$.

Reference [25] proposed a benchmarking model of supplier development where they identified the most significant critical success factors (CSFs) and classified into four groups; 1) supplier related factors, 2) secondary factors related to supplier, 3) manufacturer related factors, and 4) manufacturer and supplier related factors in order to adopt successful supplier development. Moreover, researchers have focused on the firm's operations strategy inclined towards supplier development and improved supplier performance. They highlighted some supplier development approaches and drivers that are most important supporting factors in transforming buyers' efforts into supplier development and performance improvement $[26,27]$ and $[8]$.

Supplier development strategies include the most significant supporting approaches that help buyers to enhance the overall operational performance. These 
approaches include; supplier assessment, competitive pressure, supplier incentives, and direct involvement. This process of supplier development was discussed and tested by [20] and [4] in their articles but later on, [3] developed a conceptual framework for supplier development and improved buyer supplier relationships.

Reference [3] highlighted an evolutionary supplier development route which leads towards improved relationship performance. Supplier development framework was developed based on a detailed literature review on supplier development and buyersupplier relationship which provides the successful strategies not only to develop suppliers but to improve long term relationships with suppliers [3]. It identified four main steps lead toward supplier development; 1) supplier assessment, 2) competitive pressure, 3) supplier incentives, and 4) direct involvement. Each of the steps includes several activities that ensure supplier development to enhance firm's competitive advantage.

\section{Supplier assessment}

In supplier development strategic framework, supplier assessment is the first part to be started with supplier development process. Reference [28] stated that supplier selection, supplier assessment, and their involvement are the most important actions a buying firm should concentrate on. Therefore, many researchers provided a notion of supplier's assessment in strategic decision making process [2931] and [32] to attain operational supply chain [33]. Similarly, when firms are focused to utilize their resources in a best possible way, they try to improve inter-organizational performances. This way, suppliers can be involved into the new product development processes which lead towards supplier assessment to improved business relationship performance [34] and [35].

Further, [36] presented a detailed literature review of performance criteria in supplier selection and evaluation in order to sustain competitive advantage. He identified the most significant supplier evaluation and selection criteria models from an in-depth literature review. Three main supplier evaluation methods (i.e. categorical method, weighted point, and cost ratio) which are helpful for companies to implement supplier evaluation. Based on intense literature review, he argued that weighted point model is more appropriate supplier evaluation model because of its precise and clear outcomes to the decision makers.

Certification and evaluation guarantee firm's performance by motivating suppliers to produce at their best and to enhance their capabilities [20,37] and
[38]. Further, it supports to evaluate supplier's current and expected performance and helps in better communication between the parties to improve their business performance. Reference [20] highlighted the importance of certification and evaluation in supplier development process and stated that it provides not only a competitive edge to buyers to assess their suppliers' performance but a strategic way to set a vision for suppliers. Similarly, supplier assessment is a critical success source of evaluating the competency, quality, technical know-how, cost, and delivery capability of suppliers [39] and [26]. Feedback in supplier assessment is a useful tool which contains the important information about the suppliers' performance. It helps suppliers to improve their operations intact with buyer firm's requirements [20].

\section{Competitive pressure}

Buyers implement another supplier development approach competitive pressure which ensures the quality and improved performance of suppliers [41]. In this vein, firms utilize different market forces to build a competitive pressure for suppliers to deliver their best. This supplier development strategy provides three folded advantages to the firms, 1) to analyze supplier's capability and performance, 2) provide motivation to other suppliers to improve quality in their operations, and 3) build long term business relationships [20]. Further, competitive pressure is a key source of getting improved suppliers' performance in terms of quality, cost, and delivery [40] and [41].

Therefore, supplier development strategies include multiple suppliers' assessment and threats of switching to other suppliers which help buying firms to get higher standard products and services from their suppliers. This approach develops a healthy and competitive environment for suppliers and motivates them by providing high quality supplies with a low cost. Competitive bids from several suppliers, short term contracts, and use of developed bidding details help buying firms to attain a comparatively low price [20, 42] and [26]. However, buyer will resist threatening suppliers in case of some certain switching costs [43].

\section{Supplier incentives}

Supplier incentives are another useful supplier development approach. Buyers motivate their suppliers by offering supplier incentives in different forms. This strategy keeps suppliers motivated and intact with buyers' requirements and help suppliers to improve their supply base and operational capabilities [27] and [22]. Similarly, this approach becomes key 
motivators and critical success factor to suppliers to develop their production competency with improved performance and also to build strong relationship between both parties [25]. On the other hand, suppliers will resist or will be unwilling to keep high quality products and services and long term relationships if incentives are not offered to them. Therefore, this strategy plays a pivotal role by transforming buyers' incentives into suppliers' high quality products and services and improved operational performance [44].

Suppliers' performance is influenced indirectly by supplier assessment and supplier incentives efforts by buying firms. This results in improved business performance in form of increased business volume and future business for suppliers. These efforts foster the thrust of suppliers to perform well through providing best supply to buyers not only for their benefits but also to build long term relationships. Literature has focused more on operations and provides the required supplies to buyers which positively influence knowledge transfer activities [22, 4] and [27].

\section{Direct involvement}

Direct involvement is a preemptive strategy which helps buying firms in developing suppliers and relationships [27] and [20]. Different direct involvement methods are important success factors for companies to implement successfully supplier development programs [25]. These methods include by investing capital and equipment in supplier operations [40] and [27], partially acquiring the suppliers as [45] exemplified about the acquisition ratio of Toyota and Nissan. Similarly, investments in human and organizational resources motivate organizations to be involved and develop supplier performance [4]. This novel idea is not only used in supplier development but it also offers a holistic depiction of long term buyer-supplier relationships. Reference [46] and [47] concluded with the importance of transaction specific investments as a useful factor in transaction cost and uncertainty reduction between buyers and suppliers.

Reference [19] also highlighted the importance of suppliers' involvement in business relationships which result in empowering buyer-supplier relationships. Several researchers in literature have underlined the most significant direct involvement' factors that help in enhancing the supplier development performance. For example; site visits, training and education, technical support, and capital and human resources investments are the most substantial ones that transform suppliers in producing good quality products along with enhanced process capability [5, 48] and [49].
Further, [4] also have discussed the importance of these factors in supplier development process. They also have highlighted the important role of top management into supplier development programs to provide a strategic view of supplier's performance and competency [4]. Reference [20] operationalized the concept future business incentives to operational knowledge transfer prior to establish direct involvement which allows firms to continue longer term relationships with their suppliers to transfer tacit knowledge and excel competitively.

\section{Supplier development to buyer-supplier relationship development}

Firms are eager to implement supplier development programs not only to benefit operational performance through improved product manufacturing competencies but also to develop buyer-supplier relationships. Strategic supplier development activities are utmost important drivers of developing long term buyer-supplier relationships. A conceptual framework of [3] is a useful example of supplier development process towards buyer-supplier relationship performance. The concept of supply chain network is a support for organizations to employ the available resources in such a successful manner where businesses focus on inter-organizational cooperation [34].

Therefore, several researchers have explained the logic behind the supplier development and buyersupplier relationship factors of supplier selection and supplier involvement in strategic decision making and efficient supply chain separately [29-32] and [33]. Reference [29] developed a performance measurement system (PMS) in order to enhance supplier relationship management activities in a successful way. They argued that PMS supports to evaluate the performance gap better which ultimately provides a platform in strategic decision making to meet the challenges successfully. The efforts of supplier development including capital and human resource investments positively impact the relationship performance of buyers and suppliers [48]. Consequently, this study develops and implements an integrated framework of supplier development activities to buyer-supplier relationship development.

Transaction specific investments in education and training and direct involvement of buyers and suppliers in supplier development programs are a foundation of developing business relationships [14] and [50]. Moreover, effective communication, long term strategic goals and cooperation between buyers and suppliers lead towards twofold benefits; 1) supplier development, and 2) relationship development [11, 51] and [39]. In the same vein, supplier evaluation 
has a vital role in developing buyer-supplier relationships which demands careful evaluation of suppliers regularly. After careful and successful supplier' evaluation, buyers can propose improvement requirements to gain and maintain competitive advantage. These efforts help suppliers not only to improve their competences but also develop a rationale of operational performance between them [52].

Similarly, developed trust between buyers and suppliers support them in supplier development programs to improve capabilities and in relationship specific investments. These efforts are classified as important actions in the literature of supply chain to improve the relationship performance [14]. Trust always resist the opportunism and increase the impact of buyer's assets specificity in business relationships [48]. In result, they concluded with three dimensions of supplier development consequences; competitive advantage, supplier performance, and buyer-supplier relationship development.

Integration of buyers' purchasing strategies with corporate competitive approaches establishes an environment of supplier development as well as competitive advantage. It includes; market acceptability, quality, cost and improved product development process. These factors are quite important in supplier development programs that lead towards relationship developments [53]. Likewise, [19] pointed out key competitive priorities; cost, quality, time and flexibility that result in competitive advantage for buying firms. They have stated that supplier commitment is another important factor for continuous performance improvement. In this way, [14] argued that suppliers will resist in relationship specific investments if buying firms do not show a potential interest for a relationship or investments. Thus, employed supplier development efforts for long term business relationships will create an opportunity for both buyers and suppliers to improve their capabilities and performances $[20,22]$ and [54].

Supply chain literature on buyer-supplier relationship and supplier development is fragmented and lacking because of missing link between the objectives of supplier development and business relationships. Reference [54] has also mentioned a research gap close to this research where differences exist in supplier development approaches and performance. The process of supplier development approaches and their objectives are missing towards developing relationships. Therefore, [21] mentioned the different short term but immediate and long term objectives of supplier development approaches and their effects in developing relationships. This study integrates and fills the research gap by not only combining the sig- nificant factors of supplier development efforts to relationship development but also validate the following extended research framework empirically.

The extended framework in Fig. 1 clarifies the process of current research. By extending the research framework provided by [3], this study provides an empirical evidence of validating the proposed research framework. In supplier development process, buyers and suppliers need to develop relationship focused investments and information sharing activities that will improve the performance in four key competencies (cost, quality, time, and flexibility) as well as supplier's competency will be increased [55, 56] and [25]. All important factors of supplier development approaches are important in developing buyersupplier relationships in supply chain networks. Integrated value creation requires actions from both buyers and suppliers to synchronize the collective competencies to develop the operations and relationship performance [21].

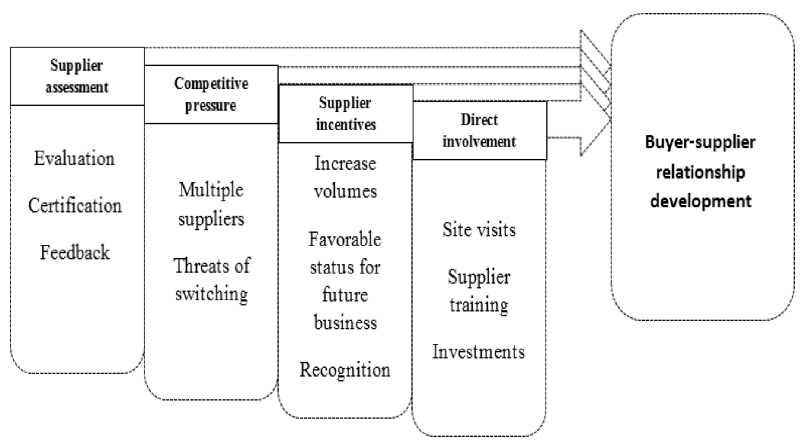

Fig. 1. Extended research framework of supplier development to buyer-supplier relationship.

Similarly, several studies have been published explaining the empirical outcomes of supplier development approaches towards improved buyer-supplier relationships through suppliers' integration, collaborative product development and planning, and information system etc. [57-62] and [63]. Further, the results of supplier development approaches clearly demonstrate not only a positive impact on firm's financial performance but also enhancing the operational competencies [61, 64] and [65]. Likewise, [1] argued that product oriented firms are more eager to implement supplier development approaches than service oriented. Communication, top management, supplier evaluation, and supplier strategic objectives are the key factor in the process of supplier development and buyer-supplier relationship development $[61,63,64]$ and [10].

Supplier development approaches have been dominated in building deep supplier relationships. Reference [66] presented a detailed study of build- 
ing supplier relationships along with six distinct steps. They argued that developing supplier's competencies, commitments, threats of switching, feedbacks, innovative capabilities, information sharing, and joint investments to improve operations provide significant opportunities to buyers in developing strong relationships with their key suppliers. In the same way, [67] proposed two approaches of developing buyer-supplier relationships through supplier development and integration action plans. A generic process model of [22] also demonstrates the supplier development through ten systematic steps to implement and develop relationships with suppliers.

Our study offers an in-sight of supplier development strategies, but particularly focuses upon how supplier development strategies can be implemented successfully and how they effect on buyer-supplier relationship. We identify critical supplier development factors within the strategic supply chain strategies, and demonstrate their mutual support implementing supplier development programs and buyer-supplier relationship. Therefore, this study extends the framework provided by [3] and implement and validate the extended research framework in a case study. This study provides the opportunities to firms to implement supplier development approaches strategically and develop business relationship to improve operational and relationship performance.

\section{Research design and methods}

This study adopts exploratory case study as the methodological approach for the research where the purpose is to improve a detailed understanding of supplier development approaches and their implementations for buyer-supplier relationship development in the selected case [68,69] and [70]. This study is based on extending the research framework provided by [3] by implementing in this case to find out how instigated supplier development approaches develop buyer-supplier relationships. Case study method is a suitable research method to employ when the research phenomenon is complex and challenging. Therefore, this method assists in this study to highlight the significant supplier development approaches in buyer-supplier development in a real world context $[71,68]$ and [70]. Thus, a case study is advantageous where the possibility of evolving accurate results extracted from data collection process to categorize supplier development approaches and strategies in development of business relationships [72] and [73].

The purpose of qualitative research is to comprehend the research field being studied [74]. Reference [75] has explained that inductive reasoning is a re- search method which is the most significant part of the research and starts a cluster of observations to develop theory or generalization. The deficiency of qualitative studies on this topic directed us to highlight the importance of question "how" and "what" factors effecting in supplier development and to identify the process of supplier development based on real practice [76]. This research design permits a comprehensive within case analysis to describe the generalizability level of evolving results [77].

A manufacturing Finnish case company and its key supplier were selected to acquire data related to supplier development approaches through interviews. The reason of selecting this case company and its supplier was a part of dynamic project of supplier development implemented in this case. This supplier produces capital products for the case company and purchasing volume is very high. A total of twenty interviews (11 from buyer, 9 from supplier) were conducted in 2013 from the top management of buyer and supplier to increase the richness of information. The respondents held top and mid-level positions in the firms including strategic managers, operation managers, and project managers who were directly involved in decision making and implementation. Semi-structured interview questionnaire including measurement substance of supplier development approaches was utilized to attain the comprehension from both buyers and suppliers [78]. Each interview lasted an average of 1-2 hour and conducted face-toface with voice recording. It was transcribed later on to ensure high degree of reliability and traceability $[72,79]$ and [80]. This technique helped us to cover different functional areas with a different perspective of supplier development approaches and their impact on buyer-supplier relationship. By following the recommended process of [79] and [81], one author was truly engaged with data collection process throughout.

Table 1

List of Respondents with their Position in Case Company.

\begin{tabular}{l|c|c}
\hline Job title & $\begin{array}{c}\text { No. } \\
\text { of } \\
\text { interviews }\end{array}$ & $\begin{array}{c}\text { Approximate } \\
\text { time } \\
\text { of interview }\end{array}$ \\
\hline
\end{tabular}

Buyer's Interviews

\begin{tabular}{l|c|l}
\hline $\begin{array}{l}\text { Strategic Managers } \\
\text { (Top management) }\end{array}$ & 3 & $1: 30$ hours/interview \\
\hline Operational Managers & 5 & About 1 hour/interview \\
\hline $\begin{array}{l}\text { Supplier Development } \\
\text { Mangers }\end{array}$ & 3 & 2 hours/interview \\
\hline \multicolumn{2}{|c}{ Supplier's Interview } \\
\hline $\begin{array}{l}\text { Top Management } \\
\text { Team Members }\end{array}$ & 2 & $1: 30$ hours/interview \\
\hline Operational Managers & 7 & $1-2$ hour/interview \\
\hline Total & $\mathbf{2 0}$ & \\
\hline
\end{tabular}

Volume 7 • Number 1 • March 2016 


\section{Propositions based on case analysis}

The proposed supplier development framework is tested empirically in dynamic business environment. The case company is operating in engineering high technology business, where the main customers are global corporates. Business environment in case company is extremely dynamic where production load is fluctuating $+/-30 \%$, which means that supplier should be extremely flexible and agile. Case company has a wider suppliers network (50 suppliers approximately) in Europe and Asia. One of its key suppliers was chosen for this study where the case company implemented supplier development program. The propositions suggested in this study were derived from the in-depth case study and the most critical supplier development approaches in buyer-supplier relationship were identified.

\section{Supplier assessment}

Supplier assessment is a significant part of supplier development program [4]. The most common phase in supplier assessment is when the relationship between buyer and supplier get formulated. In this case, this key supplier was evaluated using supplier evaluation process including the evaluation of its technical capabilities, quality, and delivery performance. Quality of the delivery was the most important criteria in supplier assessment process because of case company's high market integrity. Acceptance certification was provided to communicate their expectations to supplier after fulfilling all the required standards. Continuous supplier evaluation and feedback for supplier's awareness of performance and case company's expectations are ensured. Top management respondents from both (buyer and supplier) were convinced about the importance of constructive feedback in supplier development program. Discussion with respondents from buyer and supplier reveals that

"...feedback and certification are extremely important for supplier assessment to develop the operational competency, performance and process development. Moreover, it provides a baseline to set standards for supplier's improvements and operational knowledge transfer activities."

Assessing current performance of suppliers provides enough knowledge about the development potential of supplier which in result enhances supplier development activities [4] and [26]. Similarly, in this case supplier assessment has been a resourceful action for continuous improvements in quality and production process. These activities help not only in developing suppliers and operations but also a signif- icant source of relationship development. Trust likely stimulates and continuously improves supplier development process which has been seen in this case as one of the significance factors. It has found a very helpful tool for buyer in order to measure the supplier's performance and to develop buyer-supplier relationship. The role of top management is quite crucial in this case. As one top manager of top management from buyer mentioned that:

“... supplier assessment always contributes in required performance outcomes for both buyer and supplier to build strong relationships with our supplier. Because this firm is our key supplier, we always are keen to launch such actions which ultimately enhance the coordination with suppliers to develop strategic long-term relationships."

Moreover, evaluation and certification process implementation in buying firm create the opportunities to ensure the quality standards and a significant part of supplier development program. Discussion with respondents reveals the fact that this step stands first in supplier development program which ultimately support in continuing the following steps but most importantly a baseline for relationship development. Accordingly:

Proposition 1: The stronger the supplier assessment including evaluation, certification, and feedback, the successful supplier development program implementation comes to an existence with a moderate impact on relationship development.

\section{Competitive pressure}

Competitive pressure is another significant tool in strategic supplier development approaches where firms utilize external forces to keep up the pressure on suppliers [40, 41] and [4]. This motivational and competitive factor helps in improving the supplier's process competency and in extracting price benefits. In this case while implementing supplier development program, we found interesting and sensitive notions. Because the supplier is the key actor in buying firm's operations, competitive pressure strategy was found in a negative association with buyer-supplier relationship development but only in favor of buyer. This approach keep supplier cost competitive and efficient in its operations as Project Manager from buyer mentioned that:

"... competitive pressure is one of the key approaches to keep suppliers cost competitiveness and efficiency. Practically, this means that there should be multiple suppliers which could deliver same component or sub assembly which will cause to keep the competition up and create the threat of switching situation for supplier." 
The competitive pressure was seen in the case company as well, which validates this approach well. Competitive pressure motivates supplier to develop its operational processes, production methods, supply chain management, operative efficiency, and customer service. These are the key standard requirements of case company from their supplier. In this case, there are two more suppliers who could deliver the same products to the firm. Therefore, it creates a threat of switching in buyer-supplier relationship environment and keep supplier motivated. Case company always communicates the resources of other suppliers to its key supplier in order to let its supplier keep engaged with required quality.

From buyer-supplier relationship aspect in this case, this strategy of supplier development negatively effects on relationship development. This interesting finding was revealed while talking to one of the management team members from supplier as he mentioned that:

“...threat of switching can demotivate our operations at the times and create reluctance between us, but we still try to do our best in fulfilling the requirements from buyer. Further, we have invested our resources for our potential buyer and want to do business for longer term."

Even though, buying firm keeps developing its suppliers equally and measuring and evaluating their performances. Performance is monitored by utilizing the most significant measures; quality, cost, and punctuality. In this case, buying firm try to develop its key suppliers equally and introduce new technologies by knowledge transfer activities. The developed production and delivery process method by supplier is not shared with other supplier to keep them intact in improving their production and technological advances as well as to be cost competitive for buying firm. Moreover, during relationship with supplier, the cost efficiency has been developed enough which is a important evidence to show that competitive pressure in supplier development is very useful practical approach. Competitive pressure could develop buying firm and supplier relationship especially when supplier is confident that they are able to continue deep cooperation with buying firm. Therefore:

Proposition 2: Competitive pressure strategy including multiple suppliers and threats of switching in supplier development approaches positively effects in favor of buyer firm, but negatively impact buyersupplier relationship development.

\section{Supplier incentive}

Supplier incentive is another significant supplier development strategy to keep the suppliers moti- vated which includes cost savings, recognition in increased volumes, and favorable status for future business $[27,67]$ and [4]. This case study is a successful example of implementing supplier incentives in order to gain competitive advantage and improved business relationship performance. Case company assists its key supplier by sharing knowledge to improve operational outcomes. Incentives have been found very successful strategy in knowledge transfer as well as positive performance improvement in this case. In discussion with buyer's top management, it reveals that:

“... supplier incentives ultimately provide us better operational performance from our key supplier and it keeps them motivated in improving their process and technological developments. We rate their performance accordingly and provide an opportunity and incentives in increased business volume."

In the supplier development and buyer-supplier relationship framework, supplier incentives are increase volumes, favorable status for future business and recognition for improved performance. In this case study, the case company's strategy is to grow their business volume with supplier every year, which means that the company is seeking to develop business relationship. Case company's business volume has been increased already about $10-20 \%$ per year since the relationship started. This has been a significant motivator for supplier to develop their operational processes and keep cost efficiency up. Similarly, when the volume has been increased, the capacity utilization was more efficient which in result created cost efficiency.

Increased purchasing volume is very important approach in developing buyer-supplier relationship. Case company makes sure by giving a favorable status to its supplier for future business growth. Consequently, this strategy has been developed in this case study so that possibilities of incentives were provided to its supplier in order to develop buyer-supplier relationship performance. Recognitions from buying firms to its supplier made high business performance possible along with a longer term relationship. Moreover, this strategy has been seen a very useful tool in developing trust between buyer and supplier which in due course results in supplier development success and buyer-supplier relationship development. For the reason, supplier development project manager argued that:

“... recognition has been important for us to improve our operations towards buyer. This strategy is very useful and satisfied with our strategic goals which always motivate us to enhance the production and delivery quality continuously. Further, it allows 
us to open up our capabilities in front of buyer to implement operational improvements accordingly."

Thus, the analyzed supplier incentives strategy provides the following proposition:

Proposition 3: Continuous supplier incentives strategy enhances the business performance of both buyer and supplier. The most frequent supplier incentives strategy implements, the strongest buyersupplier relationship will be developed.

\section{Direct involvement}

Direct involvement is the last and important step of our framework in supplier development strategies and transaction-specific supplier development [27] and [14]. Direct involvement from buyer plays a significant role not only in developing suppliers but also improves buyer-supplier relationship performance [20,48] and [82]. This study includes site visits, supplier training, and investments as supplier development strategies to implement supplier development program. While implementing direct involvement strategy in this particular supplier development program, it was found that buyer acted proactively and directly in these activities to show up their interests in developing supplier for better performance. Investments in supplier operations by buyer made supplier more committed towards the required operational quality. It also supports supplier's potential to enhance their operational competency which made a win-win situation for both buyer and supplier. Operational manager from buyer highlighted the importance of direct involvement in following statement:

"... our direct involvement provides an opportunity to supplier to think in combined strategic way which in result demonstrates the commitment from both parties. This kind of activities always cause in developing longer term business relationship. Supplier's site visits have significant value in our operations because of the nature of product our supplier provide."

Site visits are important especially when readymade product are produced in the supplier production facility and the quality assurance of readymade products are done in suppliers premises. During the site visits, production process was evaluated visually and developed according to the feedback. This case demonstrate frequent supplier's site visit (at least once in a month) to follow agreed development activities in order to develop the whole supply chain. Supplier training is another important part of direct involvement from buyer to integrate supplier and enhance the relationship trust. In many cases, suppliers which produce ready products are small and medium sized companies. They do not usually have enough resources to organize specialized trainings for their employees; buyer therefore plays an extremely important role here. Consequently, discussion with a top management member from supplier reveals that:

". . training is extremely important in our operations which support us to fulfil the required quality and operational performance by buyer. Supplier training is done in many ways for example; technological training and process quality training which is resourceful in developing our performance. Buyer organizes the resources for training and all the related employees participate to learn different operational innovations and technologies."

One very intensive training was "lean training" organized by buyer in this case which was a tailormade project for supplier to develop production processes and increase performance. Typical investments have also been made in production for example machining centers tools and measurement systems in this case company to enhance the production efficiency. These investments are a significant part in developing collaboration with supplier which in result enhances the relationship performance. It could be stated that buyer-supplier relationship is developed well during activities like site visits, supplier training, and investments for the suppliers. Accordingly:

Proposition 4: The higher the direct involvement activities by buyer are, the higher chances of supplier development success are along with a positive impact on buyer-supplier relationship development.

Table 2 summarizes the results of this study and highlights the most interesting findings. It clearly demonstrates the impact of supplier development determinants on supplier development program implementation and buyer-supplier relationship. The results in Table 2 indicate that implementing supplier development programs, supplier assessment activities are the prerequisites in providing opportunities to evaluate supplier continuously in order to kick start a successful supplier development project along with competitive advantage. This finding is consistent with [4] where they found it the most important factor for undertaking operational knowledge transfer activities. On the other hand, it has a moderate impact on developing buyer-supplier relationship because of being a prerequisite in supplier development program. Similarly, competitive pressure keeps the supplier intact with the required quality and production efficiency. The results posit that competitive pressures are in favor of buying firm to keep their supplier motivated toward quality and competency and can be an important part of supplier develop- 
ment. However, because of threats of switching, it negatively influences buyer-supplier relationship development.

Table 2

Supplier development strategies and their impact on SD and BSR.

\begin{tabular}{l|l|l}
\hline \multicolumn{1}{c|}{$\begin{array}{c}\text { Supplier } \\
\text { strategelopment }\end{array}$} & $\begin{array}{l}\text { Impact } \\
\text { on supplier } \\
\text { development } \\
\text { project }\end{array}$ & \multicolumn{1}{|c}{$\begin{array}{c}\text { Impact } \\
\text { on buyer-supplier } \\
\text { relationship }\end{array}$} \\
\hline $\begin{array}{l}\text { Supplier } \\
\text { Assessment }\end{array}$ & $\begin{array}{l}\text { Successfully im- } \\
\text { plemented with } \\
\text { positive impact on } \\
\text { SD }\end{array}$ & $\begin{array}{l}\text { Moderate impact } \\
\text { on BSR develop- } \\
\text { ment im- }\end{array}$ \\
\hline Competitive & $\begin{array}{l}\text { Successfully im- } \\
\text { plemented with } \\
\text { positive impact on } \\
\text { SD }\end{array}$ & $\begin{array}{l}\text { Negative im- } \\
\text { pact on BSR } \\
\text { development }\end{array}$ \\
\hline $\begin{array}{l}\text { Supplier } \\
\text { Incentives }\end{array}$ & $\begin{array}{l}\text { Successfully im- } \\
\text { plemented with } \\
\text { positive impact on } \\
\text { SD }\end{array}$ & $\begin{array}{l}\text { Highly Positive } \\
\text { impact on BSR } \\
\text { development }\end{array}$ \\
\hline Direct & $\begin{array}{l}\text { Successfully im- } \\
\text { plemented with } \\
\text { positive impact } \\
\text { SD }\end{array}$ & $\begin{array}{l}\text { Highly positive } \\
\text { impact on BSR } \\
\text { development }\end{array}$ \\
\hline
\end{tabular}

Moreover, supplier incentives in current supplier development programs have been perceived interestingly positive from both buyer and supplier. Supplier appreciated the effort of incentives made by buyer and highlighted as an important prerequisite for buyer-supplier relationship development. It does not only keep supplier motivated towards quality and operational competency but also motivate them to cooperate in any case. A high impact on buyer-supplier relationship was seen, which demonstrate the importance of this factor in supplier development program. Lastly, direct involvement from buyer in supplier development program has been seen quite important in current case study. Top management's strategic involvement in supplier development results in longer term relationships and commitments and tacit knowledge transfer. This result is consistent with [10] and [4] who found the top management involvement/direct involvement strongly effecting longer term commitment. In our case, it implemented successfully in supplier development program and provided a strong support in developing business relationship.

Therefore, the analysis indicates that direct involvement and supplier incentives are the strong strategies of supplier development program which have a strong positive impact on developing business relationship. Although, supplier assessment moderately effect relationship development, it strongly effect in supplier development implementation. Com- petitive pressure has interestingly become a complex determinant of supplier development in our framework implementation where case company needs to undertake it seriously to come up with the most suitable solution to gain competitive advantage.

\section{Conclusions and findings}

Supplier development and buyer supplier relationship development are dominant in today's global and dynamic business environment. Buying firms are keen to develop long-term relationships with their business partners to overcome the challenges postured by current market environment. In this scenario, practitioners are more focused towards cost minimization to improve the competitiveness by developing proper supplier integrations' projects. For the purpose, this study focused on implementing a unique combined framework of supplier development strategies to develop buyer-supplier relationship. Four significant supplier development strategies (i.e. supplier assessment, competitive pressure, supplier incentives, and direct involvement) were empirically tested and verified in order to develop business relationship with an in-depth case study methodology. The results of our case study supported the theory based supplier development research framework.

Supplier development is a strategic process followed by buying firms to develop their key suppliers in order to enhance the punctuality, shorten lead times, and operational quality and to decrease total cost of ownership. Therefore, this empirical case study research results in a developed framework of supplier development being tested and validated based on extensive literature review. The research tested a supplier development framework providing numerous strategic in-sights concerning how implementing supplier development strategies result in developing buyer-supplier relationship. The findings reveal that supplier development strategies are significant strategic tools to develop buyer-supplier relationships and increase the supplier's performance and capabilities. Most interestingly, supplier incentives and direct involvement were found as strategic significant strategies for overwhelming business relationship. Suggested framework along with propositions is a unique combination of useful solutions for tactical and strategic management's decision making and also valid for academic researchers to develop supplier development theories.

Organizations always strive to construct effective and competitive supply chain networks by enhancing the competency and operational quality of their key suppliers [4]. Similarly, implementing supplier devel- 
opment strategies develop operational performance of suppliers which in return supports the buyer's successful and effective supply base. Top management role of buyer and supplier in implementing supplier development strategies acts as a significant facilitator in trust building. This permits both buyer and supplier to share important information to achieve their business objectives and to develop the operational capabilities. Moreover, supplier evaluation is a significant determinant of supplier development program which allows firms to keep the supplier's operations consistent according to their required operational competency. Consequently, by implanting all the determinants of supplier development intact, buyer-supplier relationship is developed along with their operational performance. In addition, both parties' willingness and interest in supplier development program is an important facilitator which ultimately create opportunities to improve operational and relationship performance.

This study provides a unique research framework along with empirical evidence. It contributes in provision of two-folded competitive advantage: successful supplier development implementation and developed buyer-supplier relationship. Firms that successfully progress implement supplier development strategies in order to attain several benefits: cost efficiency, continuous quality progress, better customer services, improved delivery performance, and reduced product cycle time [10]. Therefore, this study provides a combined framework of strategies to cope with these crucial operational achievements. Furthermore, this study provides an in-sight of supplier development strategies and their impact on suppliers while implementing. Most interestingly, their impact on developing buyer-supplier relationship is presented.

\section{Further research}

Further research should focus on considering indepth investigation of trust and communication factors along with the proposed supplier development approaches in a global business environment. The propositions developed in our study need to be investigated further whether these are generally applicable to other dynamic business environment. Moreover, this study represents a single manufacturing case in Finland only. It will be interesting to apply these propositions in several cases across the Finland and in other industrial settings. It will provide an opportunity to analyze how supplier development strategies influence buyer-supplier relationship in different industry contexts. Further studies can interestingly find out whether firms can build up strong relationships with their suppliers using these supplier development approaches, and if such improvements need further stages and factors. All in all, our study has presented that supplier development approaches include critical strategies exposing at the same time new opportunities for additional qualitative and quantitative research.

This paper emerges from the research project FIMECC S4Fleet. The financial support of the Finnish Funding Agency for Technology and Innovation is gratefully acknowledged.

The project is supported by OTKA (K 115542).

\section{References}

[1] Krause D.R., Scannell T.V., Supplier development practices: product- and service-based industry comparisons, The Journal of Supply Chain Management, 38, 2, 13-21, 2002.

[2] Krause D.R., Supplier development: current practices and outcomes, International Journal of Purchasing and Materials Management, 33, 2, 12-19, 1997.

[3] Sillanpää I., Shahzad K., Sillanpää E., Supplier development and buyer-supplier relationship strategies - a literature review, International Journal of Procurement Management, 8, 1, 227-250, 2015.

[4] Modi S.B., Mabert V.A., Supplier development: improving supplier performance through knowledge transfer, Journal of Operations Management, 25, 1, 42-64, 2007.

[5] Krause D.R., Ellram L.M., Critical elements of supplier development: the buying-firm perspective, European Journal of Purchasing and Supply Management, 3, 1, 21-31, 1997.

[6] Lintukangas K., Supplier relationship management capability in global supply management, International Journal of Procurement Management, 4, 1, 1-19, 2011.

[7] Sucky E., Durst S.M., Supplier development: current status of empirical research, International Journal of Procurement Management, 6, 1, 92-127, 2013.

[8] Hartley J.L., Choi T.Y., Supplier development: customers as a catalyst of process change, Business Horizons, 39, 4, 37-44, 1996.

[9] Krause D.R., Ellram L.M., Success factors in supplier development, International Journal of Physical Distribution and Logistics Management, 27, 1, 3952, 1997.

[10] Li W., Humphreys P.K., Yeung A.C., Cheng T.C.E., The impact of supplier development on buyer com- 
petitive advantage: A path analytic model, International Journal of Production Economics, 135, 1, 353-366, 2012.

[11] Watts C.A., Hahn C.K., Supplier development programs: an empirical analysis, International Journal of Purchasing and Materials Management, 29, 2, 11$17,1993$.

[12] Lieberman M., Asaba S., Inventory reduction and productivity growth: a comparison of Japanese and US automotive sectors, Managerial and Decision Economics, 18, 73-85, 1997.

[13] Loppacher J.S., Cagliano R., Spina G., Key drivers of buyer-supplier relationships in global sourcing strategies, International Journal of Procurement Management, 4, 2, 156-180, 2011.

[14] Krause D.R., The antecedents of buying firm's efforts to improve suppliers, Journal of Operations Management, 17, 2, 205-224, 1999.

[15] Leenders M.R., Supplier development, Journal of Purchasing, 2, 4, 47-62, 1966.

[16] Pfeffer J., Salancik G.R., The External Control of Organizations: A Resource Dependence Perspective, Harper \& Row, Stanford University Press, 1978.

[17] Thompson J.D., Organizations in Action: Social Science Bases of Administrative, McGraw-Hill, New York, 1967.

[18] Humphreys P.K., Shiu W.K., Chan F.T.S., Collaborative buyer-supplier relationships in Hong Kong manufacturing firms, Supply Chain Management, 6, 4, 152-162, 2001.

[19] Krause D.R., Handfield R.B., Tyler B.B., The relationships between supplier development, commitment, social capital accumulation and performance improvement, Journal of Operations Management, 25, 2, 528-545, 2007.

[20] Krause D.R., Scannell T.V., Calantone R.J., A structural analysis of the effectiveness of buying firms' strategies to improve supplier performance, Decision Sciences, 31, 1, 33-54, 2000.

[21] Wagner S.M., Krause D.R., Supplier development: communication approaches, activities and goals, International Journal of Production Research, 47, 12, 3161-3171, 2009.

[22] Krause D.R., Handfield R.B., Scannell, T.V., An empirical investigation of supplier development: Reactive and strategic processes, Journal of Operations Management, 17, 1, 39-58, 1998.

[23] Krause D.R., Handfield R.B., Developing a WorldClass Supply Base, Center for Advanced Purchasing Studies, Tempe, AZ, 1999.
[24] Handfield R.B., Krause D.R., Scannell T.V., Monczka R.M., Avoid the pitfalls in supplier development, Sloan Management Review, 41, 2, 37-49, 2000.

[25] Routroy S., Pradhan S.K., Evaluating the critical success factors of supplier development: a case study, Benchmarking: An International Journal, 20, 3, 322-341, 2013.

[26] Hahn C.K., Watts C.A., Kim K.Y., The supplier development program: a conceptual model, Journal of Purchasing and Materials Management, 26, 2, 2-7, 1990.

[27] Monczka R.M., Trent R.J., Callahan T.J., Supply base strategies to maximize supplier performance, International Journal of Physical Distribution and Logistics Management, 23, 4, 42-54, 1993.

[28] Araz C., Ozkarahan I., Supplier evaluation and management system for strategic sourcing based on a new multicriteria sorting procedure, International Journal of Production Economics, 106, 2, 585-606, 2007.

[29] Choy K.L., Lee W.B., Lo V., Development of a case based intelligent customer - supplier relationship management system, Expert Systems with Applications, 23, 3, 281-297, 2002.

[30] Song M., Di Benedetto C.A., Supplier's involvement and success of radical new product development in new ventures, Journal of Operations Management, $26,1,1-22,2008$.

[31] Hammami R., Temponi C., Frein Y., A scenariobased stochastic model for supplier selection in global context with multiple buyers, currency fluctuation uncertainties, and price discounts, European Journal of Operational Research, 233, 1, 159-170, 2014.

[32] Ho W., Xu X., Dey P.K., Multi-criteria decision making approaches for supplier evaluation and selection: A literature review, European Journal of Operational Research, 202, 1, 16-24, 2010.

[33] Fawcett S.E., Magnan G.M., McCarter M.W., Benefits, barriers, and bridges to effective supply chain management, Supply Chain Management: An International Journal, 13, 1, 35-48, 2008.

[34] Handfield R.B., Nichols E.L., Supply chain redesign: Transforming supply chains into integrated value systems, FT Press, 2002.

[35] Wynstra F., Ten Pierick E., Managing supplier involvement in new product development: A portfolio approach, European Journal of Purchasing \& Supply Management, 6, 1, 49-57, 2000.

[36] Imeri S., Key Performance Criteria for Vendor Selection - A Literature Review, Management Research and Practice, 5, 2, 63-75, 2013. 
[37] Carr A.S., Pearson J.N., Strategically managed buyer-supplier relationships and performance outcomes, Journal of Operations Management, 17, 5, 497-519, 1999 .

[38] Harland C.M., Supply chain management: relationships chains and networks, British Journal of Management 7, 1, 63-80, 1996.

[39] Giunipero L.C., Motivating and monitoring JIT supplier performance, Journal of Purchasing and Materials Management, 26, 3, 19-24, 1990.

[40] Dyer J.F., Ouchi W.G., Japanese style partnership: giving companies a competitive advantage, Sloan Management Review, 35 1, 51-63, 1993.

[41] Tezuka H., Success as the source of failure? Competition and cooperation in the Japanese economy, Sloan Management Review, 38, 2, 83-93, 1997.

[42] Spekman R.E., Strategic supplier selection: Understanding long-term buyer relationships, Business Horizons, 31, 4, 75-81, 1988.

[43] Richardson J., Roumasset J., Sole sourcing, competitive sourcing, parallel sourcing: mechanisms for supplier performance, Managerial and Decision Economic, 16, 1, 71-84, 1995.

[44] Ghijsen P.W.T., Semeijn J., Ernstson S., Supplier satisfaction and commitment: the role of influence strategies and supplier development, Journal of Purchasing and Supply Management, 16, 1, 17-26, 2010.

[45] Dyer J.H., Specialized supplier networks as a source of competitive advantage: evidence from the auto industry, Strategic Management Journal, 17, 4, 271291, 1996.

[46] Williamson O.E., The economics of organization: the transaction cost approach, American Journal of Sociology, 87, 3, 548-577, 1981.

[47] Williamson O.E., The Economic Institutions of Capitalism: Firms, Markets, Relational Contracting, Free Press, 866 Third Avenue, New York, NY, 10022, 1985.

[48] Humphreys P.K., Li W.L., Chan L.Y., The impact of supplier development on buyer-supplier performance, Omega, 32, 2, 131-143, 2004.

[49] Sánchez-Rodríguez C., Martínez-Lorente Á.R., Quality management practices in the purchasing function: an empirical study, International Journal of Operations and Production Management, 24, 7, 666-687, 2004.

[50] Joshi A.W., Stump R.L., The contingent effect of specific asset investments on joint action in manufacturer-supplier relationships: an empirical test of the moderating role of reciprocal asset invest- ments, uncertainty, and trust, Journal of the Academy of Marketing Science, 27, 3, 291-305, 1999.

[51] Newman R.G., Rhee K.A., A case study of NUMMI and its suppliers, International Journal of Purchasing and Materials Management, 26, 4, 15-20, 1990.

[52] Stuart F.I., McCutcheon D., Problem sources in establishing strategic supplier alliances, International Journal of Purchasing and Materials Management, 31, 1, 3-9, 1995.

[53] Heide J.B., John G., Alliances in industrial purchasing: the determinants of joint action in buyersupplier relationships, Journal of Marketing Research (JMR), 27, 1, 24-36, 1990.

[54] Wagner S.M., Supplier development practices: an exploratory study, European Journal of Marketing, 40, 5-6, 554-571, 2006

[55] Hunter L., Beaumont P., Sinclair D., A 'partnership' route to human resource management?, Journal of Management Studies, 33, 2, 235-257, 1996.

[56] Dyer J.H., Nobeoka K., Creating and managing high performance knowledge sharing networks: the Toyota case, Strategic Management Journal, 21, 3, 345$368,2000$.

[57] Terpend R., Tyler, B.B., Krause, D.R., Handfield, R.B., Buyer-supplier relationships: derived value over two decades, Journal of Supply Chain Management, 44, 2, 28-55, 2008.

[58] Ellram L.M., Liu B., The financial impact of supply management, Supply Chain Management Review, 6, 6, 30-37, 2002.

[59] Frohlich M.T., Westbrook R., Demand chain management in manufacturing and services: web-based integration, drivers and performance, Journal of Operations Management, 20, 6, 729-745, 2002.

[60] Narasimhan R., Kim S.W., Effect of supply chain integration on the relationship between diversification and performance: evidence from Japanese and Korean firms, Journal of Operations Management, 20, 3, 303-323, 2002.

[61] Rosenzweig E.D., Roth A.V., Dean Jr. J.W., The influence of an integration strategy on competitive capabilities and business performance: an exploratory study of consumer products manufacturers, Journal of Operations Management, 21, 4, 437-456, 2003.

[62] Droge C., Jayaram J., Vickery S.K., The effects of internal versus external integration practices on time-based performance and overall firm performance, Journal of Operations Management, 22, 6, 557-573, 2004.

[63] Petersen K.J., Ragatz G.L., Monczka R.M., An examination of collaborative planning effectiveness 
and supply chain performance, Journal of Supply Chain Management, 41, 2, 14-25, 2005.

[64] Tracey M., A holistic approach to new product development: new insights, Journal of Supply Chain Management, 40, 4, 37-55, 2004.

[65] Petersen K.J., Handfield R.B., Ragatz G.L., Supplier integration into new product development: coordinating product, process and supply chain design, Journal of Operations Management, 23, 3-4, 371$388,2005$.

[66] Liker J.K., Choi T.Y., Building deep supplier relationships, Harvard Business Review, 82, 12, 104113, 2004.

[67] Prahinski C., Benton W.C., Supplier evaluations: communication strategies to improve supplier performance, Journal of Operations Management, 22, 1, 39-62, 2004.

[68] Yin R.K., Case Study Research: Applied social research methods series, Publications S, ed. Beverly Hills, 1994.

[69] Eisenhardt K.M., Building theories from case study research, Academy of Management Review, 14, 4, 532-550, 1989 .

[70] Eisenhardt K.M., Graebner M.E., Theory building from cases: opportunities and challenges, Academy of Management Journal, 50, 1, 25-32, 2007.

[71] Bonoma T.V., Case research in marketing: opportunities, problems, and a process, Journal of Marketing Research, 199-208, 1985.

[72] Ghauri P., Designing and conducting case studies in international business research, Handbook of Qualitative Research Methods for International Business, 109-24, 2004.

[73] Yin R.K., Case Study Research: Design and Methods, Sage Publications, Print, 2003.
[74] Burrell G., Morgan G., Sociological paradigms and organizational analysis: Elements of the sociology of corporate life, London: Heinemann, 1979.

[75] Ghauri P., Grønhaug K., Research methods in business studies: A practical guide (3rd ed. ed.), Harlow: Financial Times Prentice Hall, 2005.

[76] Glaser B.G., Strauss A.L., The discovery of grounded theory: Strategies for qualitative research, Transaction Publishers, 2009.

[77] Eisenhardt K.M., Better stories and better constructs: The case for rigor and comparative logic, Academy of Management Review, 16, 3, 620-627, 1991.

[78] Bryman A., Qualitative research on leadership: A critical but appreciative review, The Leadership Quarterly, 15, 6, 729-769, 2004.

[79] Miles M.B., Huberman A.M., Qualitative data analysis: A sourcebook of new methods. In Qualitative data analysis: a sourcebook of new methods; Qualitative data analysis: a sourcebook of new methods. Sage publications, 1984.

[80] McCutcheon D.M., Meredith J.R., Conducting case study research in operations management, Journal of Operations Management, 11, 3, 239-256, 1993.

[81] Hill C.E., Thompson B.J., Williams E.N., A guide to conducting consensual qualitative research, The Counselling Psychologist, 25, 4, 517-572, 1997.

[82] Lettice F., Wyatt C., Evans S., Buyer-supplier partnerships during product design and development in the global automotive sector: who invests, in what and when?, International Journal of Production Economics, 127, 2, 309-319, 2010.

[83] MacDuffie J., Helper S., Creating lean suppliers: Diffusing lean production through the supply chain, California Management Review, 39, 4, 118-151, 1997. 